\title{
Identification of functional DNA variants in the constitutive promoter region of MDM2
}

\author{
Marie-Eve Lalonde ${ }^{1}$, Manon Ouimet ${ }^{1}$, Mathieu Larivière ${ }^{1}$, Ekaterini A Kritikou ${ }^{1}$ and Daniel Sinnett $1,2^{*}$
}

\begin{abstract}
Although mutations in the oncoprotein murine double minute 2 (MDM2) are rare, MDM2 gene overexpression has been observed in several human tumors. Given that even modest changes in MDM2 levels might influence the p53 tumor suppressor signaling pathway, we postulated that sequence variation in the promoter region of MDM2 could lead to disregulated expression and variation in gene dosage. Two promoters have been reported for MDM2; an internal promoter (P2), which is located near the end of intron 1 and is p53-responsive, and an upstream constitutive promoter (P1), which is p53-independent. Both promoter regions contain DNA variants that could influence the expression levels of MDM2, including the well-studied single nucleotide polymorphism (SNP) SNP309, which is located in the promoter P2; i.e., upstream of exon 2. In this report, we screened the promoter P1 for DNA variants and assessed the functional impact of the corresponding SNPs. Using the dbSNP database and genotyping validation in individuals of European descent, we identified three common SNPs (-1494 G > A; indel 40 bp; and $-182 \mathrm{C}>\mathrm{G}$ ). Three major promoter haplotypes were inferred by using these three promoter SNPs together with rs2279744 (SNP309). Following subcloning into a gene reporter system, we found that two of the haplotypes significantly influenced MDM2 promoter activity in a haplotype-specific manner. Site-directed mutagenesis experiments indicated that the $40 \mathrm{bp}$ insertion/deletion variation is causing the observed allelic promoter activity. This study suggests that part of the variability in the MDM2 expression levels could be explained by allelic p53independent P1 promoter activity.
\end{abstract}

Keywords: MDM2, SNP, Promoter analysis, Functional validation, Site-directed mutagenesis

\section{Introduction}

The p53 tumor suppressor has a key role in orchestrating cellular responses to various types of stresses, including DNA damage and oncogene activation with apoptosis, cell-cycle arrest, senescence, DNA repair, cell metabolism, or autophagy [1,2]. Malfunction and mutations of $p 53$ have been found in most human cancers, leading to a deregulated p53 activity that allows cells to proliferate and survive [3]. The activity of p53 is regulated by many proteins, and one of the most extensively studied regulators of p53 is the murine double minute 2 (MDM2) oncoprotein. MDM2 can regulate p53 activity in different ways and even modest modifications of MDM2 levels can affect the p53 pathway [4]. Firstly, MDM2 directly binds to the p53 transactivation domain,

\footnotetext{
* Correspondence: daniel.sinnett@umontreal.ca
${ }^{1}$ Division of Hematology-Oncology, Research Center, Sainte-Justine Hospital,

* Correspondence: daniel.sinnett@umontreal.ca
'Division of Hematology-Oncology, Research Center, Sainte-Justine Hospital, 3175 Chemin de la Cote-Sainte-Catherine, Montreal H3T 1C5, Canada ${ }^{2}$ Department of Pediatrics, Faculty of Medicine, University of Montreal, 2Department of Pediatrics, Faculty
Montreal QC H3T 1C5, Canada
}

\section{() Biomed Central}

(c) 2012 Lalonde et al.; licensee BioMed Central Ltd. This is an Open Access article distributed under the terms of the Creative Commons Attribution License (http://creativecommons.org/licenses/by/2.0), which permits unrestricted use, distribution, and reproduction in any medium, provided the original work is properly cited.

thus inhibiting its transcriptional activity. Secondly, MDM2 promotes ubiquitin-dependent proteasomal degradation of p53 by functioning as an E3 ubiquitin ligase $[5,6]$. Finally, MDM2 shuttles p53 out of the nucleus to the cytoplasm of the cell, promoting the degradation of p53. Importantly, MDM2 forms a negative-feedback loop in regulating p53 activity, in which p53 induces transcription of $M D M 2$, and, in turn, the MDM2 protein inhibits p53 activity (reviewed by Momand et al. [7]).

Although mutations in $M D M 2$ are rare, MDM2 overexpression is observed in a number of human tumors due to various mechanisms including gene amplification [8-10] and increased transcription [11,12]. MDM2 overexpression predisposed transgenic mice to spontaneous tumor formation [13] and therefore, overexpression of MDM2 may substitute for inactivating mutations in p53 [9]. Because MDM2 is an important negative regulator of p53 activity, overexpression of MDM2 can result in 
the inhibition of p53-mediated-transcriptional activation, thereby promoting human carcinogenesis.

Functional sequence variants in promoter regions can lead to variable gene expression levels $[14,15]$; single nucleotide polymorphisms (SNPs) in promoters of genes implicated in DNA-damage responses and apoptosis could have an impact in an individual's susceptibility to develop cancer [16-21]. Because MDM2 is a key component of the p53-mediated DNA-damage response, promoter SNPs in this gene might influence this highly regulated pathway by modifying cellular MDM2 protein levels [22]. The $M D M 2$ gene has a basal promoter (P1) and an alternative promoter (P2) starting in the intron 1 [23]. The promoter P2 contains a p53-responsive element and has been shown to regulate MDM2 levels in stressed cells, whereas the promoter P1 functions mainly in a non-stressed environment [23,24]. The rs2279744 (SNP309) in the intronic p53-responsive promoter of the MDM2 gene has been shown to increase the affinity of the transcriptional activator $\mathrm{Sp} 1$, resulting in higher levels of MDM2 mRNA and protein. This SNP has been shown to attenuate apoptotic activity and accelerate tumor formation [22,25-27]. Several studies have reported associations between rs2279744 and the risk of different types of cancer [28-30]; however, this association has not always been confirmed [31-33]. In an attempt to obtain a more complete view of the $M D M 2$ promoters, we determined the SNP content and the haplotype structure of the constitutive P1 promoter. Here, we show that distinct P1 promoter haplotypes can influence the p53-independent promoter activity in an allele-specific manner.

\section{Methods}

\section{SNP discovery in MDM2 proximal promoter region}

The initial search for promoter SNPs (pSNPs) in MDM2 proximal promoter defined as $2.0 \mathrm{~kb}$ upstream of the transcription start site was done using the dbSNP database (build 128) [34]. Seven SNPs were selected for genotyping in a panel of 91 individuals of Western European descent. The Institutional Review Board approved the research protocol and informed consent was obtained from all participants. The corresponding promoter region was amplified in one polymerase chain reaction (PCR) fragment in a $50 \mu \mathrm{L}$ reaction volume, using the following conditions: 20 pmole of 5'AAAGCCCAAATTTCCTTGCT3' (forward) and $5^{\prime}$ CTCCATCTTTCCGACACACA3' (reverse) primers, $2 \mathrm{mM} \mathrm{MgCl}_{2}, 0.2 \mathrm{mM}$ deoxynucleoside triphosphates (dNTPs), $1 \times$ Fast Start Taq DNA polymerase buffer and GC rich buffer, 2U Fast Start Taq DNA polymerase (Roche Diagnostics, Laval, Canada) and $15 \mathrm{ng}$ of genomic DNA. The PCR program was $95^{\circ} \mathrm{C}$ for $3 \mathrm{~min} ; 10$ cycles with a denaturation at $95^{\circ} \mathrm{C}$ for $15 \mathrm{~s}$; annealing at $55-50^{\circ} \mathrm{C}$ (each cycle decreases by $0.5^{\circ} \mathrm{C}$ ) for $20 \mathrm{~s}$ and elongation at $68^{\circ} \mathrm{C}$ for $2 \mathrm{~min}$; followed by 25 cycles at $50^{\circ}$ $\mathrm{C}$ for annealing. The amplicons were dot-blotted in duplicate on a nylon membrane and were hybridized with allele-specific oligonucleotides (ASOs) as previously described [35]. Oligonucleotide probes specific for each promoter SNP were used for ASO analysis and are available upon request. A $40 \mathrm{bp}$ insertion/deletion (indel) polymorphism was genotyped by amplification of a $260 \mathrm{bp}$ fragment containing the indel region followed by electrophoresis of the resulting amplicons on a 3\% agarose gel to detect one (homozygous) or two bands (heterozygous). PCR conditions were as follows: 20 pmole of 5'TTTCCTTTCTGGTAGGCTGG3' (forward) and 5'CACCTACTTTCCCACAGAGA3' (reverse) primers, $1.5 \mathrm{mM} \mathrm{MgCl}, 0.2 \mathrm{mM}$ dNTPs, 1× Fast Start Taq DNA polymerase buffer and GC rich buffer, 1U Fast Start Taq DNA polymerase (Roche Diagnostics, Laval, Canada), and $15 \mathrm{ng}$ of genomic DNA. The PCR program was $95^{\circ} \mathrm{C}$ for $3 \mathrm{~min} ; 32$ cycles with a denaturation at $95^{\circ} \mathrm{C}$ for $30 \mathrm{~s}$; annealing at $52^{\circ} \mathrm{C}$ for $30 \mathrm{~s}$; and elongation at $72^{\circ} \mathrm{C}$ for $20 \mathrm{~s}$. Hardy-Weinberg equilibrium was tested with a $\chi^{2}$ test for goodness of fit. Haplotypes were generated by PHASE software (version 2; University of Washington, Seattle, WA, USA) [36].

\section{Gene reporter assays and site-directed mutagenesis Constructs}

The two major promoter haplotypes (approximately $2.0 \mathrm{~kb}$ region) were amplified from genomic DNA of known homozygous individuals and cloned individually in the promoterless pGL3basic Firefly luciferase vector (Promega Corp., Fitchburg, WI, USA) using the Gateway Technology (Invitrogen Corporation, Carlsbad, CA, USA). Specific mutations were introduced by sitedirected mutagenesis (Quickchange multi site-directed mutagenesis kit, Stratagene from Agilent Technologies, Santa Clara, CA, USA) according to the manufacturer's instructions. Clones chosen for transfection were sequenced to confirm the presence of the SNPs and then purified using the Qiagen plasmid mini kit (Qiagen Company, Toronto, Canada) prior to transfection.

\section{Transfection}

The resulting constructs were used to transiently transfect three cell lines (HeLa, HepG2, and JEG3) using lipofectamine reagent according to the manufacturer's protocol (Invitrogen). Constructs (99 ng) and SV40driven (1 ng) Renilla luciferase cytomegalovirus (CMV) immediate early enhancer/promoter region (pRL-CMV) (ratio 100:1) were co-transfected to control transfection efficiency. The pGL3basic promoterless plasmid (Promega) was used as a negative control and the pGL3SV40 plasmid (Promega) was used as a positive control. The transfected cells were plated in 96-well plates with 
approximately $6 \times 10^{4}$ cells per well. The cells were harvested $24 \mathrm{~h}$ following transfection, and luciferase reporter gene activity was measured with dual-luciferase reporter assay system (Promega) in a SpectraMax 190 luminometer according to the manufacturer's protocol (Molecular Devices, LLC, Sunnyvale, CA, USA). Firefly luciferase activities of the allelic constructs were normalized using the Renilla luciferase pRL-CMV activity. The results were expressed as the ratio of Firefly luciferase activity divided by the pRL-CMV internal control activity and expressed as relative luciferase (means \pm standard deviation) of four replicates. Three independent experiments were carried out for each cell line. Statistical analyses were performed using unpaired Student's $t$ test to determine $p$ values. Global $p$ value is calculated with Fischer's inverse Chi-squared test [37].

\section{In silico predictions of putative TFBS}

MatInspector program from Genomatix Software GmbH (Bayerstrasse, Munich, Germany, www.genomatix.de) was used to determine the presence of putative binding sites for known transcription factors. The predicted gain or loss of putative transcription factor binding site (TFBS) due to a given SNP was determined by the optimized matrix threshold as defined in the MatInspector program.

\section{Results}

The search for SNPs in the constitutive P1 promoter of $M D M 2$ led to the identification of eight pSNPs, including a $40 \mathrm{bp}$ indel (see Table 1). In addition to these pSNPs, we included the well-studied rs2279744 located in the P2 promoter for haplotype analysis (see Figure 1 for a schematic representation of $M D M 2$ promoters). By genotyping a panel of 91 unrelated Western Europeans, we found four pSNPs (-1494 G > A, rs1144944; indel 40 bp, rs3730485;

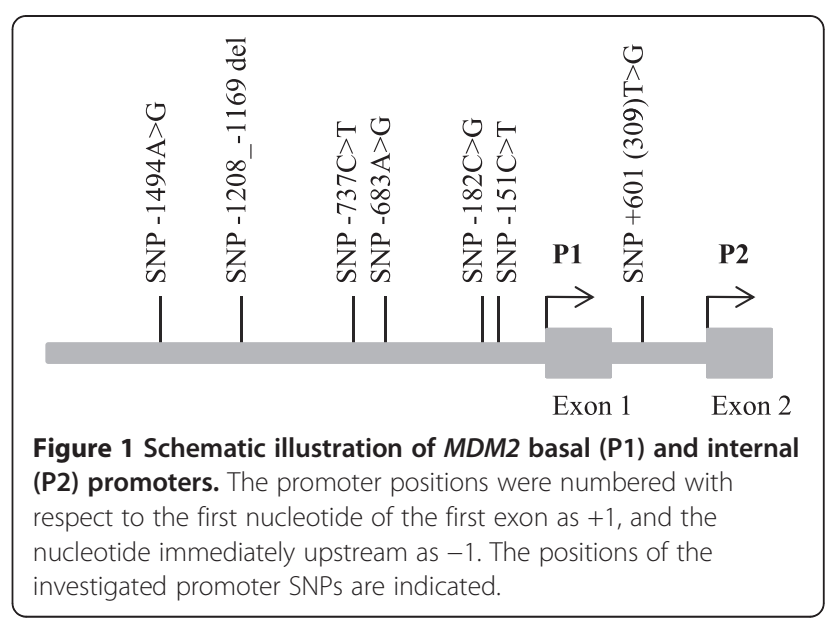

-182 C > G, rs937282; and SNP309/601 T > G, rs2279744) to be polymorphic. For rs2279744 the observed minor allele frequency of $35 \%$ was similar to the one previously reported for Caucasians [38]. Among the five nonpolymorphic SNPs, both $-1166 \mathrm{~T}>\mathrm{G}$ (rs2904506) and $-1164 \mathrm{C}>\mathrm{G}$ (rs3930427) are located in the $40 \mathrm{bp}$ indel sequence thus creating in some individuals a near identical (except for 2 bps) tandem duplication. Therefore, individuals carrying the deletion behave like they have different alleles at these two positions. Because single variants might not be sufficient to capture the genetic variability relative to a given phenotype, we constructed haplotypes using all four polymorphic pSNPs. Based on these data, we estimated haplotype phase and the corresponding frequencies (Table 2). The three most common promoter haplotypes $(1 \mathrm{~A}, 1 \mathrm{~B}$, and 2 ) represented $92.3 \%$ of the observed haplotypes in Europeans. Haplotypes 1A and 1B differ at rs2279744, whereas haplotype 2 differs at all four positions (Figure 2a). To evaluate the extent of linkage disequilibrium between the SNPs studied, we measured $D^{\prime}$

Table 1 List of the SNPs found in dbSNP database for MDM2 promoter

\begin{tabular}{|c|c|c|c|}
\hline Rs number $^{\mathrm{a}}$ & Position $^{\text {b }}$ & SNPs ID ${ }^{c}$ & $\mathrm{MAF}^{\mathrm{d}}$ \\
\hline rs1144944 & g.67,486,752 G>A & -1494 & $25 \%$ \\
\hline rs3730485 & g.67,487,038_67,487,077del & $40 \mathrm{bp}$ indel $(-1208$ to -1169$)$ & $37 \%$ \\
\hline rs2904506 & g.67,487,080 T>G & -1166 & - \\
\hline rs3930427 & g.67,487,082 C> G & -1164 & - \\
\hline rs3730486 & g. $67,487,509$ C > T & -737 & $0 \%$ \\
\hline rs3730487 & g. $67,487,563 \mathrm{~A}>\mathrm{G}$ & -683 & $0 \%$ \\
\hline rs937282 & g.67, 688,064 C > G & -182 & $50 \%$ \\
\hline rs3730491 & g.67,488,095 C>T & -151 & $0 \%$ \\
\hline rs2279744 & g. $67,488,847 \mathrm{~T}>\mathrm{G}$ & +601 & $35 \%$ \\
\hline
\end{tabular}

${ }^{\mathrm{a}}$ From dbSNP build 128.

${ }^{\mathrm{b}} \mathrm{NCBI}$ Build 36.1 .

CPosition relative to the transcription start site (based on reference sequence mRNA).

${ }^{\mathrm{d}}$ Minor allele frequencies (MAF) were calculated with 91 unrelated European individuals in this study.

${ }^{\mathrm{e}}$ For comparison purposes, we included SNP309 (+601 in our nomenclature) associated with the internal promoter P2. 
Table 2 Most frequent MDM2 promoter haplotypes

\begin{tabular}{cccccc}
\hline Haplotype & $\mathbf{- 1 4 9 4} \mathbf{G}>\mathbf{A}$ & $\mathbf{4 0}$ bp deletion & $\mathbf{- 1 8 2} \mathbf{C}>\mathbf{G}$ & $\mathbf{+ 3 0 9} \mathbf{~}>\mathbf{G}$ & Frequency $^{\mathbf{a}}$ \\
\hline 1A & $\mathrm{A}$ & No deletion & $\mathrm{C}$ & $\mathrm{G}$ & $36.8 \%$ \\
1B & $\mathrm{A}$ & No deletion & $\mathrm{C}$ & $\mathrm{T}$ & $17.0 \%$ \\
2 & $\mathrm{G}$ & Deletion & $\mathrm{G}$ & $\mathrm{T}$ & $38.5 \%$ \\
\hline
\end{tabular}

${ }^{a}$ Frequencies calculated with genotyping results of the 91 unrelated European individuals.

and $R^{2}$; these values between rs1144944 and rs937282 are 0.977 and 0.934 , respectively, and 0.968 and 0.471 between these two SNPs and rs2279744. This indicates that rs2279744 (SNP309) is tightly linked with the P1 promoter's variants.

To assess the functional impact of the major promoter haplotypes 1 and 2, we subcloned the promoter haplotypes in the promoterless pGL3 basic Firefly luciferase reporter vector and we carried out transient transfection experiments for each haplotype-specific constructs in three cell lines (Figure 2b). Because these constructs contain only the proximal P1 promoter (rs2279744 was not included), we could not test differential promoter activities between haplotypes $1 \mathrm{~A}$ and $1 \mathrm{~B}$. Significant differences were found between $\mathrm{H} 1$ and $\mathrm{H} 2$ (Figure 2a), with the promoter haplotype $\mathrm{H} 1$ having stronger promoter activity in all cell lines tested (Figure $2 \mathrm{~b}$ ). The relative luciferase activity driven by $\mathrm{H} 1$ was up to 2.3-fold higher than the luciferase levels driven by $\mathrm{H} 2$, indicating variable haplotype-specific expression levels of MDM2. The $309 \mathrm{G}$ allele was only present in $1.0 \%$ of individuals carrying haplotypes other than H1A (data not shown); therefore, European individuals carrying the allele $\mathrm{G}$ of this SNP are more likely to have the high P1 promoter activity haplotype because of the linkage disequilibrium.

Using in silico predictive tools, none of these SNPs seem to affect the putative binding of known transcription factors. However, the $40 \mathrm{bp}$ indel contains several

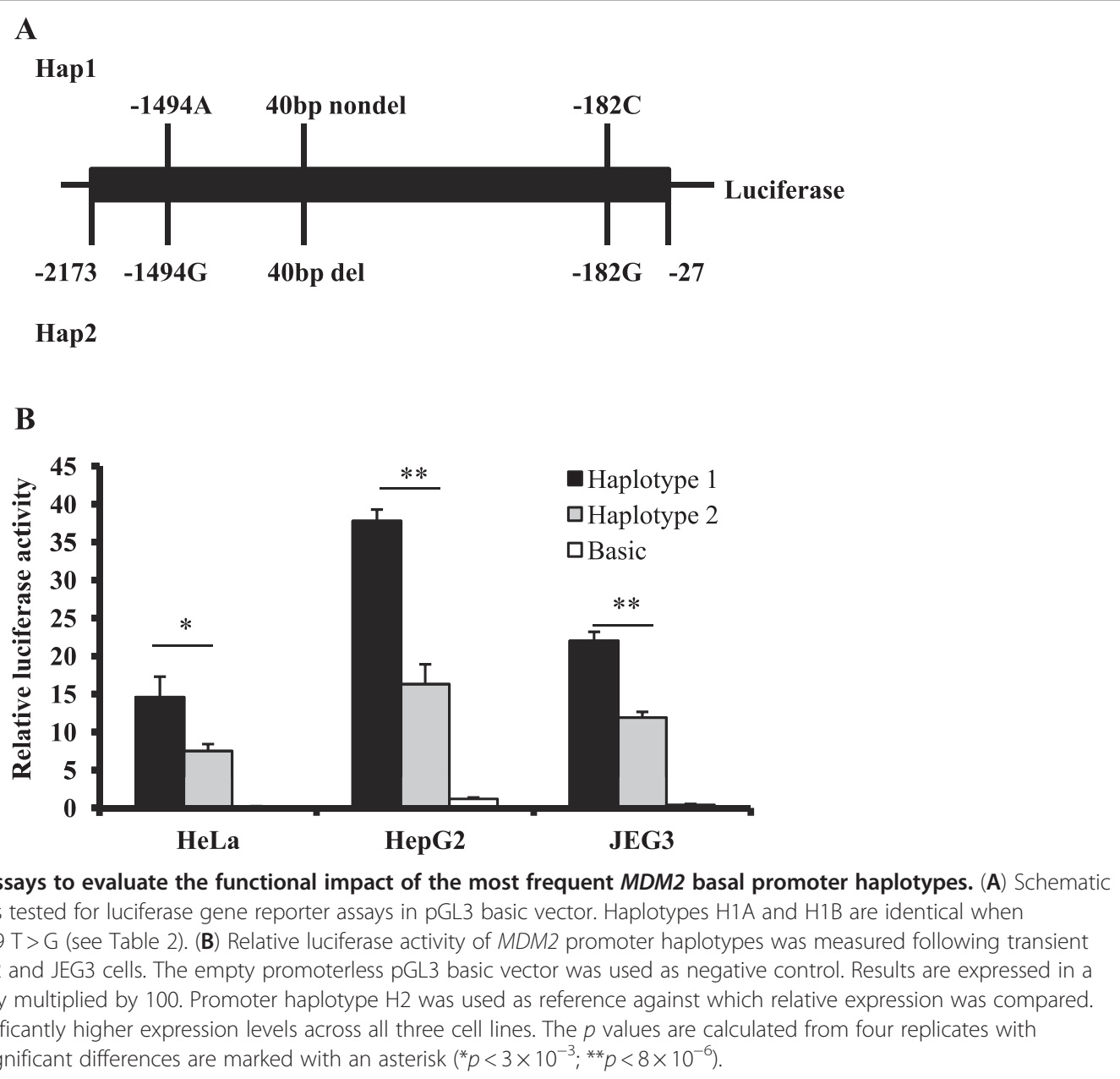


predicted transcription factor binding sites (data not shown). In an attempt to identify the cis-acting elements responsible for the observed changes in MDM2 P1 promoter activity, we modified the allele combination in both haplotypes using site-directed mutagenesis (Figure 3). None of the allele combinations in the context of the $40 \mathrm{bp}$ insertion (defining H1) significantly affected the promoter activity of the corresponding $\mathrm{H} 1$-derived haplotypes. In the context of the $40 \mathrm{bp}$ deletion (defining $\mathrm{H} 2$ ), the $-1494 \mathrm{~A}>\mathrm{G}$ variant (rs1144944) does not affect the H2-derived promoter activity. However, the introduction of allele $-182 \mathrm{C}$ (instead of allele G) completely abrogated the promoter activity when combined with the $40 \mathrm{bp}$ deletion compared to the $\mathrm{H} 1$-derived construct. This indicates the role of the $40 \mathrm{bp}$ indel variation in the observed allelic promoter activity and the presence of a putative cis-acting element at position -182 . Taken together, these results support the functional impact of MDM2 promoter haplotypes on the promoter activity.

\section{Discussion}

In more than half the tumors with a fault in the p53 pathway, TP53 itself is not mutated but the p53 pathway is abrogated. Mechanisms that result in this abrogation include increased expression of MDM2 [7] and deletion or epigenetic inactivation of the p53-positive regulator and MDM2 inhibitor ADP-ribosylating factor $[39,40]$. MDM2 might influence cancer risk through its interaction with other key cancer genes with various functions [41-44]. The MDM2 oncogene is overexpressed in various human cancers and its expression correlates with the phenotypes of high-grade, late-stage, and resistant tumors $[45,46]$. MDM2 has an important role in cancer development, mostly through inactivation of the p53 pathway [46]. By contrast, the p53-independent MDM2mediated tumorigenesis is less understood.

At the promoter level, regulation of MDM2 expression is complex involving two promoters, P1 and P2, which govern transcripts with different translational potentials. In this report, we characterized the two major haplotypes that correspond to the upstream p53-independent constitutive P1 promoter. Unlike the p53-responsive P2 promoter, the P1 promoter lacks an identified TATA box and p53-responsive element $[23,47]$. We showed that the constitutive expression levels of MDM2 might at least be partially regulated by distinct promoter SNPs, particularly the 40 bp deletion and the corresponding promoter haplotypes (see Results section). Previous work has shown a

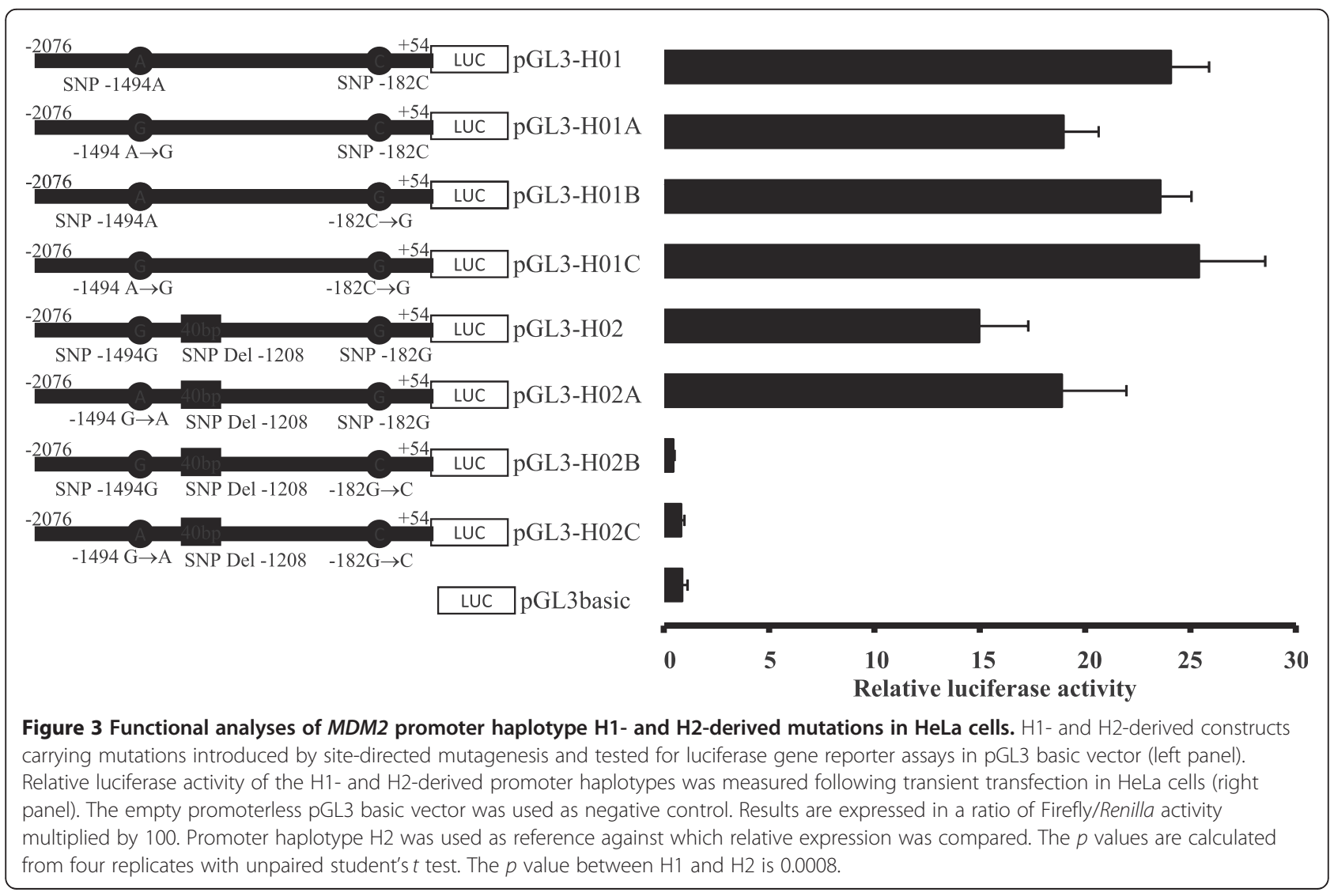


correlation of rs937282 with allelic differences in promoter activity, with the allele $-182 \mathrm{G}$ having high promoter activity [48]. However, in our hands, the $-182 \mathrm{G}$ allele was associated with the low-activity P1 promoter haplotype. This discrepancy could be explained by the fact that the extended promoter P1 haplotype was not determined in their study. The latter is particularly relevant when considering the observed impact of the SNP-182 C > G alleles in the context of the presence/absence of the $40 \mathrm{bp}$ deletion.

Most previous studies have been focused on the impact of rs2279744 (SNP309 $(\mathrm{T}>\mathrm{G})$ ), which is located in the p53-dependent promoter P2. In vitro studies have shown that the allele SNP309G increased the affinity of Sp1 transcription activator for a putative binding site and increase the steady-state levels of $M D M 2$, which in turn reduced the basal p53 levels [26,49]. Although many studies have attempted to assess the association between rs2279744 and different cancer types, the data remains controversial $[27,38,50]$. A clear association between rs2279744 and cancer risk was reported in Asians but not in Europeans and in Africans in a meta-analysis [38]. The explanation for this observation is unclear but could be explained by genetic heterogeneity because the observed SNP309 frequencies are variable in different populations ranging from approximately $50 \%$ in Asians to $33 \%$ and $10 \%$ in Caucasians and Africans, respectively [38]. A recent meta-analysis indicates that MDM2 SNP309 serves as a tumor susceptibility marker [51]. Finally, the transcription factor influenced by rs2279744 might be cell-type specific so that this variant does not affect MDM2 expression in certain tissues [22].

These conflicting rather than conclusive results might be explained by several reasons, including linkage disequilibrium between SNP309 and another, yet unknown, functional SNP in MDM2. This linkage disequilibrium could also contribute to cancer associations with SNP309 suggesting that haplotype constructions of MDM2 pSNPs would add force to these association studies. In this report, we showed that SNP309G was associated with the high P1 promoter activity haplotype. We believe that looking at the impact of haplotypes rather than individual SNPs on promoter activity is a more suitable approach because it takes into account the putative interaction between SNPs. In conclusion, this study revealed differential constitutive $\mathrm{P} 1$ promoter activities, at least in vitro. This observation implies that individuals who carry distinct p53-independent P1 promoter haplotypes might have a modified risk for cancer development. Association studies in large patient cohorts will helps us to further determine the importance of these haplotypes in cancer.

\section{Competing interests}

The authors declare that they have no competing interests.

\section{Authors' contributions}

MEL carried out most molecular genetics experiments and drafted the manuscript. MO and ML participated in some molecular studies. MEL, MO EK, and DS contributed to the interpretation of the data. MEL, DS and EK conceived the study, and participated in its design and coordination. All authors read and approved the final manuscript.

\section{Acknowledgments}

This study was supported by research funds provided by the Canadian Institutes of Health Research as well as Genome Quebec/Canada. MEL is the recipient of a Natural Sciences and Engineering Research Council (NSERC) Canada Graduate's scholarship. DS holds the François-Karl Viau Chair in Pediatric Oncogenomics and is a scholar of the Fonds de la Recherche en Santé du Québec (FRSQ).

Received: 22 May 2012 Accepted: 31 May 2012

Published: 1 September 2012

\section{References}

1. Hu W, Feng Z, Ma L, Wagner J, Rice JJ, Stolovitsky G, Levine AJ: A single nucleotide polymorphism in the MDM2 gene disrupts the oscillation of p53 and MDM2 levels in cells. Cancer Res 2007, 67:2757-2765.

2. Harris SL, Levine AJ: The p53 pathway: positive and negative feedback loops. Oncogene 2005, 24:2899-2908.

3. Bennett WP, Hussain SP, Vahakangas KH, Khan MA, Shields PG, Harris CC Molecular epidemiology of human cancer risk: gene-environment interactions and p53 mutation spectrum in human lung cancer. J Pathol 1999, 187:8-18.

4. Bond GL, Hu W, Levine AJ: MDM2 is a central node in the $\mathrm{p} 53$ pathway: 12 years and counting. Curr Cancer Drug Targets 2005, 5:3-8.

5. Haupt $Y$, Maya R, Kazaz A, Oren M: Mdm2 promotes the rapid degradation of p53. Nature 1997, 387:296-299.

6. Kubbutat $\mathrm{MH}$, Jones $\mathrm{SN}$, Vousden $\mathrm{KH}$ : Regulation of p53 stability by Mdm2. Nature 1997, 387:299-303

7. Momand J, Zambetti GP, Olson DC, George D, Levine AJ: The mdm-2 oncogene product forms a complex with the p53 protein and inhibits p53-mediated transactivation. Cell 1992, 69:1237-1245.

8. Momand J, Jung D, Wilczynski S, Niland J: The MDM2 gene amplification database. Nucleic Acids Res 1998, 26:3453-3459.

9. Oliner JD, Kinzler KW, Meltzer PS, George DL, Vogelstein B: Amplification of a gene encoding a p53-associated protein in human sarcomas. Nature 1992, 358:80-83.

10. Meddeb M, Valent A, Danglot G, Nguyen VC, Duverger A, Fouquet F, TerrierLacombe MJ, Oberlin O, Bernheim A: MDM2 amplification in a primary alveolar rhabdomyosarcoma displaying a t(2;13)(q35; q14). Cytogenet Cell Genet 1996, 73:325-330.

11. Bueso-Ramos CE, Yang Y, deLeon E, McCown P, Stass SA, Albitar M: The human MDM-2 oncogene is overexpressed in leukemias. Blood 1993, 82:2617-2623

12. Watanabe T, Hotta T, Ichikawa A, Kinoshita T, Nagai H, Uchida T, Murate T, Saito $\mathrm{H}$ : The MDM2 oncogene overexpression in chronic lymphocytic leukemia and low-grade lymphoma of B-cell origin. Blood 1994, 84:3158-3165

13. Jones SN, Hancock AR, Vogel H, Donehower LA, Bradley A: Overexpression of $\mathrm{Mdm} 2$ in mice reveals a p53-independent role for $\mathrm{Mdm} 2$ in tumorigenesis. Proc Nat Acad Sci U S A 1998, 95:15608-15612.

14. Knight JC: Regulatory polymorphisms underlying complex disease traits. J Mol Med (Berlin, Germany) 2005, 83:97-109.

15. Pastinen $T$, Sladek R, Gurd S, Sammak A, Gel B, Lepage P, Lavergne K, Villeneuve A, Gaudin T, Brandstrom H, Beck A, Verner A, Kingsley J, Harmsen E, Labuda D, Morgan K, Vohl M-C, Naumova AK, Sinnett D, Hudson TJ: A survey of genetic and epigenetic variation affecting human gene expression. Physiol Genomics 2004, 16:184-193.

16. Park JY, Park JM, Jang JS, Choi JE, Kim KM, Cha SI, Kim CH, Kang YM, Lee WK, Kam S, Park RW, Kim IS, Lee JT, Jung TH: Caspase 9 promoter polymorphisms and risk of primary lung cancer. Hum Mol Genet 2006, 15:1963-1971.

17. Harris SL, Gil G, Robins H, Hu W, Hirshfield K, Bond E, Bond G, Levine AJ: Detection of functional single-nucleotide polymorphisms that affect apoptosis. Proc Nat Acad Sci U S A 2005, 102:16297-16302. 
18. Ho SY, Wang YJ, Chen HL, Chen CH, Chang CJ, Wang PJ, Chen HH, Guo HR: Increased risk of developing hepatocellular carcinoma associated with carriage of the TNF2 allele of the -308 tumor necrosis factor-alpha promoter gene. Cancer Causes Control 2004, 15:657-663.

19. Wagner K, Hemminki K, Grzybowska E, Klaes R, Burwinkel B, Bugert P, Schmutzler RK, Wappenschmidt B, Butkiewicz D, Pamula J, Pekala W, Försti A: Polymorphisms in genes involved in $\mathrm{GH} 1$ release and their association with breast cancer risk. Carcinogenesis 2006, 27:1867-1875

20. Ma X, Ruan G, Wang Y, Li Q, Zhu P, Qin YZ, Li JL, Liu YR, Ma D, Zhao H: Two single-nucleotide polymorphisms with linkage disequilibrium in the human programmed cell death 5 gene $5^{\prime}$ regulatory region affect promoter activity and the susceptibility of chronic myelogenous leukemia in Chinese population. Clin Cancer Res 2005, 11:8592-8599.

21. Moshynska O, Sankaran K, Saxena A: Molecular detection of the G(-248)A BAX promoter nucleotide change in B cell chronic lymphocytic leukaemia. Mol Pathol 2003, 56:205-209.

22. Bond $G L, H u$ W, Levine $A$ : A single nucleotide polymorphism in the MDM2 gene: from a molecular and cellular explanation to clinical effect. Cancer Res 2005, 65:5481-5484.

23. Zauberman A, Flusberg D, Haupt Y, Barak Y, Oren M: A functional p53responsive intronic promoter is contained within the human $\mathrm{mdm} 2$ gene. Nucleic Acids Res 1995, 23:2584-2592.

24. Ries S, Biederer C, Woods D, Shifman O, Shirasawa S, Sasazuki T, McMahon M, Oren M, McCormick F: Opposing effects of Ras on p53: transcriptional activation of mdm2 and induction of p19ARF. Cell 2000, 103:321-330.

25. Bond GL, Hirshfield KM, Kirchhoff T, Alexe G, Bond EE, Robins H, Bartel F, Taubert H, Wuerl P, Hait W, Toppmeyer D, Offit K, Levine AJ: MDM2 SNP309 accelerates tumor formation in a gender-specific and hormonedependent manner. Cancer Res 2006, 66:5104-5110.

26. Bond GL, Hu W, Bond EE, Robins H, Lutzker SG, Arva NC, Bargonetti J, Bartel F, Taubert H, Wuerl P, Onel K, Yip L, Hwang SJ, Strong LC, Lozano G, Levine $\mathrm{AJ}$ : A single nucleotide polymorphism in the MDM2 promoter attenuates the p53 tumor suppressor pathway and accelerates tumor formation in humans. Cell 2004, 119:591-602.

27. Bond GL, Menin C, Bertorelle R, Alhopuro P, Aaltonen LA, Levine AJ: MDM2 SNP309 accelerates colorectal tumour formation in women. J Med Genet 2006, 43:950-952.

28. Bond $G L$, Levine AJ: A single nucleotide polymorphism in the $p 53$ pathway interacts with gender, environmental stresses and tumor genetics to influence cancer in humans. Oncogene 2007, 26:1317-1323.

29. Dharel N, Kato N, Muroyama R, Moriyama M, Shao RX, Kawabe T, Omata M MDM2 promoter SNP309 is associated with the risk of hepatocellular carcinoma in patients with chronic hepatitis C. Clin Cancer Res 2006, 12:4867-4871

30. Ohmiya N, Taguchi A, Mabuchi N, Itoh A, Hirooka Y, Niwa Y, Goto H: MDM2 promoter polymorphism is associated with both an increased susceptibility to gastric carcinoma and poor prognosis. J Clin Oncol 2006, 24:4434-4440

31. Wilkening S, Hemminki K, Rudnai P, Gurzau E, et al: No association between MDM2 SNP309 promoter polymorphism and basal cell carcinoma of the skin. Br J Dermatol 2007, 157:375-377.

32. Petenkaya A, Bozkurt B, Akilli-Ozturk O, Kaya HS, Gur-Dedeoglu B, Yulug IG: Lack of association between the MDM2-SNP309 polymorphism and breast cancer risk. Anticancer Res 2006, 26:4975-4977.

33. Pine SR, Mechanic LE, Bowman ED, Welsh JA, Chanock SC, Shields PG, Harris CC: MDM2 SNP309 and SNP354 are not associated with lung cancer risk. Cancer Epidemiol Biomarkers Prev 2006, 15:1559-1561.

34. Sherry ST, Ward MH, Kholodov M, Baker J, Phan L, Smigielski EM, Sirotkin K: dbSNP: the NCBI database of genetic variation. Nucleic Acids Res 2001, 29:308-311.

35. Labuda D, Krajinovic M, Richer C, Skoll A, Sinnett H, Yotova V, Sinnett D: Rapid detection of CYP1A1, CYP2D6, and NAT variants by multiplex polymerase chain reaction and allele-specific oligonucleotide assay. Anal Biochem 1999, 275:84-92.

36. Stephens M, Smith NJ, Donnelly P: A new statistical method for haplotype reconstruction from population data. Am J Hum Genet 2001, 68:978-989.

37. Idelman G, Taylor JG, Tongbai R, Chen RA, Haggerty CM, Bilke S, Chanock SJ, Gardner K: Functional profiling of uncommon VCAM1 promoter polymorphisms prevalent in African American populations. Hum Mutat 2007, 28:824-829.
38. $\mathrm{Hu} Z$, Jin G, Wang L, Chen F, Wang $X$, Shen H: MDM2 promoter polymorphism snp309 contributes to tumor susceptibility: evidence from 21 case-control studies. Cancer Epidemiol Biomarkers Prev 2007, 16:2717-2723.

39. Esteller M, Cordon-Cardo C, Corn PG, Meltzer SJ, Pohar KS, Watkins DN, Capella G, Peinado MA, Matias-Guiu X, Prat J, Baylin SB, Herman JG: p14ARF silencing by promoter hypermethylation mediates abnormal intracellular localization of MDM2. Cancer Res 2001, 61:2816-2821.

40. Sherr CJ, Weber JD: The ARF/p53 pathway. Curr Opin Genet Dev 2000, 10:94-99.

41. Dobbelstein M, Wienzek S, Konig C, Roth J: Inactivation of the p53homologue p73 by the mdm2-oncoprotein. Oncogene 1999, 18:2101-2106.

42. Xiao ZX, Chen J, Levine AJ, Modjtahedi N, Xing J, Sellers WR, Livingston DM: Interaction between the retinoblastoma protein and the oncoprotein MDM2. Nature 1995, 375:694-698.

43. Zhang $Y$, Xiong $Y$, Yarbrough WG: ARF promotes MDM2 degradation and stabilizes p53: ARF-INK4a locus deletion impairs both the Rb and p53 tumor suppression pathways. Cell 1998, 92:725-734.

44. Zhang Z, Zhang R: p53-independent activities of MDM2 and their relevance to cancer therapy. Curr Cancer Drug Targets 2005, 5:9-20.

45. Dickens MP, Fitzgerald R, Fischer PM: Small-molecule inhibitors of MDM2 as new anticancer therapeutics. Semin Cancer Biol 2010, 20:10-18.

46. Brown CJ, Lain S, Verma CS, Fersht AR, Lane DP: Awakening guardian angels: drugging the p53 pathway. Nat Rev Cancer 2009, 9:862-873.

47. Barak Y, Gottlieb E, Juven-Gershon T, Oren M: Regulation of mdm2 expression by p53: alternative promoters produce transcripts with nonidentical translation potential. Genes Dev 1994, 8:1739-1749.

48. Wang M, Zhang Z, Zhu H, Fu G, Wang S, Wu D, Zhou J, Wei Q, Zhang Z: A novel functional polymorphism C1797G in the MDM2 promoter is associated with risk of bladder cancer in a Chinese population. Clin Cancer Res 2008, 14:3633-3640.

49. Arva NC, Gopen TR, Talbott KE, Campbell LE, Chicas A, White DE, Bond GL, Levine AJ, Bargonetti J: A chromatin-associated and transcriptionally inactive p53-Mdm2 complex occurs in mdm2 SNP309 homozygous cells. J Biol Chem 2005, 280:26776-26787.

50. Wilkening S, Bermejo JL, Hemminki K: MDM2 SNP309 and cancer risk: a combined analysis. Carcinogenesis 2007, 28:2262-2267.

51. Wan Y, Wu W, Yin Z, Guan P, Zhou B: MDM2 SNP309, gene-gene interaction, and tumor susceptibility: an updated meta-analysis. BMC Cancer 2011, 11:208.

doi:10.1186/1479-7364-6-15

Cite this article as: Lalonde et al:: Identification of functional DNA variants in the constitutive promoter region of MDM2. Human Genomics 2012 6:15.

\section{Submit your next manuscript to BioMed Central and take full advantage of:}

- Convenient online submission

- Thorough peer review

- No space constraints or color figure charges

- Immediate publication on acceptance

- Inclusion in PubMed, CAS, Scopus and Google Scholar

- Research which is freely available for redistribution 